\title{
A 90-year Morphodynamic Analysis in Southern Queensland (Australia)
}

Ana Paula da Silva*, Lorena G. Woortmann, Guilherme Vieira da Silva, Thomas Murray, Darrell Strauss, and Rodger Tomlinson

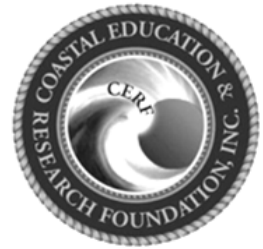

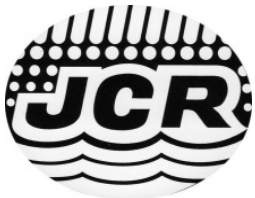

www.JCRonline.org

\begin{abstract}
Silva, A.P.; Woortmann, L.G.; Vieira da Silva, G., Murray, T.; Strauss, D., and Tomlinson, R., 2020. A 90-year Morphodynamic Analysis in Southern Queensland (Australia). In: Malvárez, G. and Navas, F. (eds.), Global Coastal Issues of 2020. Journal of Coastal Research, Special Issue No. 95, pp. 438-442. Coconut Creek (Florida), ISSN 0749-0208.

This paper investigates the beach morphology changes in response to coastal structures and wave conditions on the Southern Gold Coast region (Letitia Spit, NSW to Kirra Beach, QLD). To do so, 137 individual days - spanning approximately 90 years $(1930$ - 2017) - were analysed using remote-sensing. Images were rectified and mapped in ArcGIS 10.3, identifying sandbars, spit formations, shoreline indicator and the river delta. The analysis showed longterm trends in response to the major coastal interventions (training walls and artificial bypassing). In general, the beach equilibrium was reestablished in $\sim 10$ years after the interventions, even though this condition could mean a complete upper beach depletion. Both the river and headland bypassing systems presented changes as results of the anthropogenic structures and to natural stressors. For instance, to have a natural recovery of Point Danger bypassing, the river delta would need to rebuild, and a continuous increased longshore transport would be necessary. These conditions were observed during strong El Nino years. In addition, the bypassing systems within Coolangatta Bay showed that sediment deposits location and seasonal wave variability control the type and occurrence of the bypassing. Overall, the study proved the complex interconnection between coastal compartments that is essential to understand for having an effective coastal management. The knowledge of long-term morphodynamic processes gained with this approach can support coastal cities to maintain healthy and resilient beach systems.
\end{abstract}

ADDITIONAL INDEX WORDS: Shoreline changes, beach erosion, sand bypassing, spit development.

\section{INTRODUCTION}

To address erosion problems and protect the coastline, interventions have been used to modify local littoral processes to satisfy the coastal city's needs. However, in several cases, the introduction of one artificial structure causes issues that have to be solved by subsequent engineering solutions (Tomlinson, 1991). For instance, some coastlines around the world have experienced continuous coastal management actions for more than a century. However, long-term monitoring of the morphodynamic responses are frequently restricted to last three decades (Luijendijk et al., 2018, Vos et al., 2019), that provide the majority of the satellite imagery for remote-sensing analysis.

The analysis of the long-term history of the morphological changes is an imperative step that every coastal community would need to undertake to develop management strategies and build resilience for the future climate scenarios. Thus, the aim of this paper is to outline the morphological changes in response to 90 years of coastal interventions and climate variability on the Southern Gold Coast beaches - Kirra Beach to Rainbow Bay (QLD) - and the immediately updrift compartment - Duranbah to North Letitia Spit (NSW) (Figure 1a). This region is a typical example of several decades of coastal management and natural hazards that led to new morphodynamic equilibrium. In addition, a continuous monitoring program has been undertaken, subsidizing a long-term imagery dataset for the present study.

DOI: 10.2112/SI95-085.1 received 31 March 2019; accepted in revision 13 February 2020.

*Corresponding author: ana.dasilva@griffithuni.edu.au

${ }^{\circ}$ Coastal Education and Research Foundation, Inc. 2020

\section{Coastal Management History}

In the early 1900 's, training walls were built to stabilize the Tweed River Entrance and improve navigation (Tomlinson, 1991). In 1936 and early 1940's, tropical cyclones caused the first reported widespread erosion to the Southern Gold Coast region (Strauss et al., 2009). Then, in 1962-1964, the Tweed River training walls were extended to $300 \mathrm{~m}$ offshore in order to avoid sand accumulation at the river entrance. However, they acted as a barrier to the net northward sediment transport, reducing the sand supply to the downdrift beaches (Tomlinson, 1991). In 1967, other series of cyclones and East Coast Lows (ECL) reached Gold Coast, intensifying the erosional trends.

Under this scenario, Queensland Government (QLD Gov.) commissioned investigations that led to the implementation of an extensive beach nourishment scheme. To retain the sediment inside Coolangatta Bay (Figure 1a), a $175 \mathrm{~m}$ groyne was constructed at Kirra Point (headland). The groyne was successful in accreting Coolangatta Beach, however it prevented sand to bypass downdrift to Kirra Beach. In 1974-75, 765,000 $\mathrm{m}^{3}$ of sand was dredged from Tweed River delta and used to nourish Kirra Beach (Roelvink and Murray, 1992). In the following decade, more storms removed all sediment from the upper beach. In response, nourishment campaigns continued in the southern Gold Coast reaching 6.2 million $\mathrm{m}^{3}$ by 1990, from which $87 \%$ remained after two years (Strauss et al., 2009).

A sediment budget analysis of the Southern Gold Coast 
estimated the net effect of the training walls extension was a $7.6 \mathrm{M} \mathrm{m}^{3}$ of accretion in the updrift and $7.2 \mathrm{M} \mathrm{m}^{3}$ of erosion in the downdrift in 30 years (Roelvink and Murray, 1992). To provide a longer-term solution to the recurrent erosion, the Tweed Sand Bypassing Project (TSB) was implemented. From 1995 to 2006, 4.6 $\mathrm{M} \mathrm{m}^{3}$ of sand was dredged from the Tweed River and deposited on Southern Gold Coast beaches (Strauss et al., 2009). In 2001, permanent sand pumping started, artificially bypassing sediment from Letitia Spit to the downdrift beaches via an underground pipeline system that outlets at Point Danger (Snapper Rocks outlet) and intermittently in Duranbah and Kirra beaches (Acworth and Lawson, 2011). A series of studies were done in light of the TSB implementation and evaluating its dynamics and efficiency (Ackworth and Lawson, 2011). The results showed that the system has been successful in recovering and stabilizing the beaches from Duranbah to Kirra and keeping the navigation channel viable.

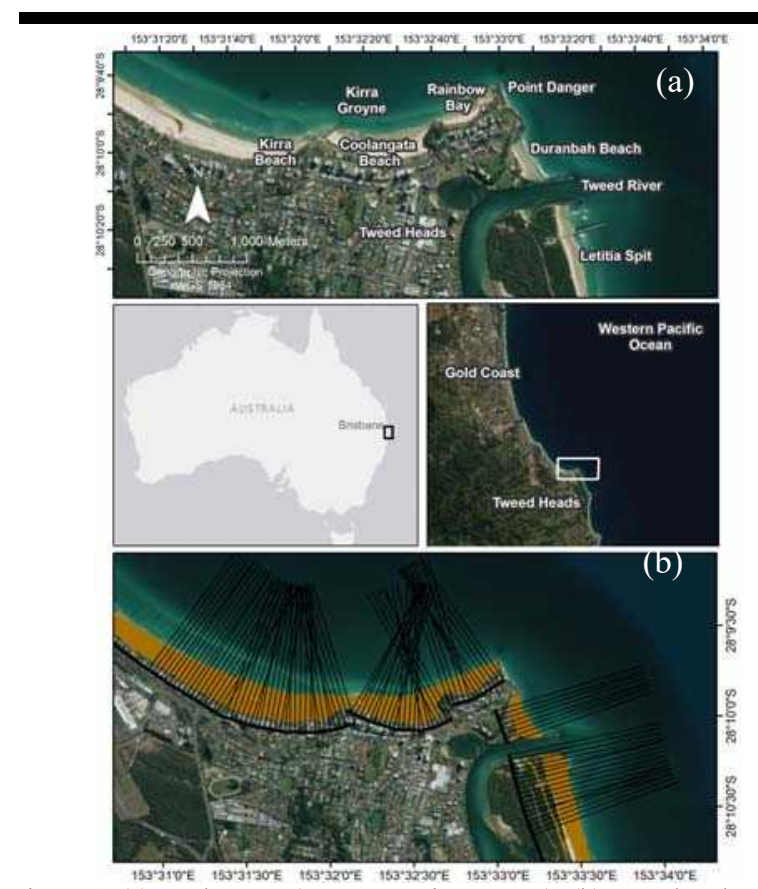

Figure 1. (a) Study Area (Source: EsrißArcGIS); (b) Wet-dry shorelines from 1930 to 2017 and DSAS transects spaced at every $50 \mathrm{~m}$ along the shore-parallel baselines from North Letitia Spit to Kirra Beach.

\section{METHODS}

A geospatial analysis was applied to a set of 300 aerial and satellite images, comprising 137 individual days from 1930 to 2017 within a variable temporal-scale. The absolute scale varied between 1:6,000 and 1:40,000 for the images from QLD Gov., and 1:12,500 for Google Earth Pro images. Image rectification was performed in a GIS environment (ESRI ${ }^{\circledR}$ ArcGIS 10.3). All the images were referenced to the World Imagery base map (ESRI ${ }^{\circledR}$ ArcMap $^{\mathrm{TM}} 10.3$ ), that provides one metre or better resolution imagery from multiple sources. At least 20 control points (CP's) were distributed evenly throughout the images, linking the coordinates from the ESRI Base map to the raster. The image transformation was done using "first-order polynomial transformation (Affine)" for the satellite images, adjusting only the scaling and positioning. The QLD Gov. images frequently presented bent or curved margins after the placement of the CP's, requiring the use of the "second-order polynomial transformation" to correct the image distortion. Images were projected in the geographic coordinate system referenced to the WGS 1984 Datum. The root mean-square (RMS) errors with $95 \%$ confidence interval (CI) was calculated for each image (Araujo et al., 2009). Maximum RMS was 5m (or $9 \mathrm{~m}$ with $95 \% \mathrm{CI}$ ) from the August 1930. The average for the dataset is of $\pm 2-3 \mathrm{~m} 95 \% \mathrm{CI}$, which is considered negligible since changes in the morphological features are on the order of ten's to hundreds of metres.

The horizontal error related to the tidal range is not possible to be obtained for each day as the time of the image acquisition it is not available. Therefore, the error was estimated from the tidal range for the region (Vieira da Silva et al., 2016a). The tidal range (Tweed River Gauge) is $1.45 \mathrm{~m}$ - excluding the $2.5 \%$ highest and $2.5 \%$ lowest tidal levels $(95 \% \mathrm{CI})$. Considering the steeper beach face $\left(2.5^{\circ}-4^{\circ}\right)$ of Duranbah, Coolangata and Kirra, the horizontal tidal error varies around 20 to $35 \mathrm{~m}$. Rainbow Bay and Letitia Spit have smoother profiles $\left(1.5^{\circ}\right.$ $2.5^{\circ}$ ) with horizontal error around 35 to $50 \mathrm{~m}$. This error is relevant to the analysis of individual days, however, it does not refut long-term trends.

Using all rectified images, the wet-dry shoreline indicator was mapped and analysed using the Digital Shoreline Analysis System (DSAS) version 4.3 (Himmelstoss, 2009). DSAS computes the distance of the shoreline vector data from a defined baseline in a determined number of regularly spaced profiles. In total, 95 profiles with $50 \mathrm{~m}$ spacing were created from Letitia Spit to Kirra Beach and used to investigate the variability of the shoreline (Figure 1b). In addition, features such as sandbars, spits and sand slugs were mapped and measured in order to describe the beach morphology variability.

\section{RESULTS}

The following results present the evolution of beach compartments in the updrift and downdrift of Point Danger headland from 1930 to 2017.

\section{Updrift Beach Compartments - Letitia to Duranbah}

Between 1930 and 1960, Letitia Spit was well-accreted, extending seaward of the original training walls (Figure 2). The Tweed River delta was regularly shifted towards northeast (NE), controlling the stability of Duranbah Beach. The delta was normally attached to the tip of Letitia Spit and identifiable up to $500 \mathrm{~m}$ offshore. The longshore sandbars (LSB) were positioned $\sim 400 \mathrm{~m}$ offshore of the shoreline. In 1956, for instance, a continuous LSB was observed bypassing the river and migrating to the downdrift of Point Danger (Figure 2).

The extension of the training walls in 1962 by $300 \mathrm{~m}$ transferred the river delta to $450 \mathrm{~m}$ offshore, and shifted its orientation from $\mathrm{NE}\left(50^{\circ}\right)$ to $\mathrm{E}\left(90^{\circ}\right)$, causing obstruction of the natural longshore sediment transport. In the first 2 years, $\sim 60 \mathrm{~m}$ of accretion was observed in north Letitia upper beach (Figure 3 ), and a further $140 \mathrm{~m}$ until early 1980's. Slight recession episodes were detected as a product of storm-wave events in 1967, 1972-73, and in 1976 due to dredging in Tweed River in 1974-75. Despite the general shoreline accretion, the maximum 
seaward position of the sandbars did not change. The average distance between the beach face and bar was shortened by 200 $\mathrm{m}$, with the exception of 1989 (Figure 2) and 2008-2009 when LSB's were observed up to $400 \mathrm{~m}$ offshore of the shoreline. This new configuration led to a steeper beach face, which is also observed in the beach profile surveys for the region. This resulted in a narrower surf zone and a lower-energy intermediate beach state similar to transverse bar-beach/low-tide terrace. Hence, the potential sediment transport was reduced and sediment deposition on the updrift of the walls was favoured.

Duranbah Beach also presented some accretion due to the training walls creating a stable embayment for the upper beach development (Figure 2). However, as Duranbah is nourished by the ebb delta shoals, the sediment input was limited while the delta was rebuilding. Therefore, the shoreline advance did not exceed $50 \mathrm{~m}$ by 1985 . The first well-formed delta observed after the training walls extension was in 1982-1983. The delta rebuilding facilitated the bypassing to Southern Gold Coast, although sediment had first to infill Duranbah profiles before migrating to the downdrift beaches. In 1986-87, a large $(160,000$ $\mathrm{m}^{2}$ above the average) delta deposit was apparent, followed by a $50 \mathrm{~m}$ shoreline advance of Duranbah in 1987-88.

From 1989 to 1996, the formation of an ebb delta attached to a LSB in Letitia Spit was recurrent, with large shoals building around Tweed River entrance and a well-nourished upper beach in Duranbah, reaching a maximum seaward extent of the shoreline in 1994-1995. Under this condition, the sediment availability led to large pulses of sand $\left(>130,000 \mathrm{~m}^{2}\right.$; largest in $1990, \sim 240,000 \mathrm{~m}^{2}$ ) (Figure 2) migrating from Duranbah to the Coolangatta Bay. Up to this moment, the largest pulses were measured in $1961\left(\sim 220,000 \mathrm{~m}^{2}\right)$ and $1972\left(\sim 230,000 \mathrm{~m}^{2}\right)$. These results indicate a natural recovery of the sediment transport towards Gold Coast, however, it was not enough to change the beaches long-term erosive state. Therefore, the nourishment campaigns persisted. From 1996-1997, substantial dredging of the Tweed River delta were performed to nourish Southern Gold Coast as part of the TSB Project. Then, Duranbah deposits were deprived of sand and consistent upper beach erosion occurred, setting shoreline position back to the early 1970's position (Figure 3).

From 2001, both Letitia Spit and Duranbah responded to the commencement of the TSB pumping. In the first 7 months, the shoreline retreated $60 \mathrm{~m}$ in Letitia Spit (Figure 3). A gradual erosion persisted in the following years, reaching the maximum landward position in 2006, with further $80 \mathrm{~m}$ of recession (Figure 3). As a consequence, a slight onshore migration of the sandbars occurred. Tweed delta was also depleted, enhancing the shoreline recession at Duranbah to a position similar to 1930's (Figure 3). After a decade of the TSB, Letitia Spit started to present shoreline accretion $(\sim 70 \mathrm{~m})$ trends again, most likely as a consequence of the adjustments to the TSB pumping rates from 2007. Since then, Letitia Spit shoreline has oscillated \pm 30 $\mathrm{m}$ from an average position, as result of natural oscillations of the sediment input and transport in this beach system as well as the tide variation. The current shoreline position at Letitia Spit is still $\sim 150 \mathrm{~m}$ seaward of the shoreline from 1930-60's. Tweed delta also started to rebuild around 2011, but its shoals are still incipient with no LSB attached to the delta and migrating towards Point Danger have been visible since 2001.

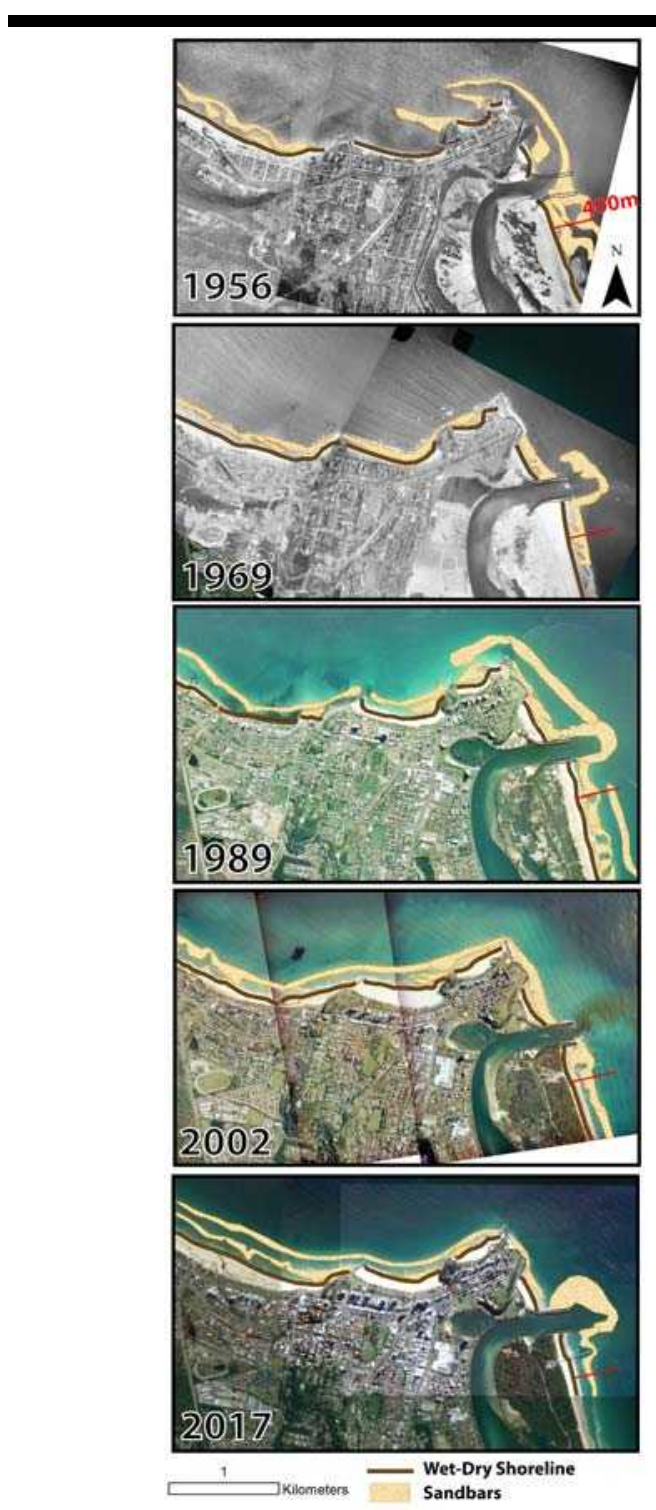

Figure 2. Beach morphology examples from 1956 (previous training walls), 1969, 1989, 2002 (after TSB), and 2017. Yellow polygons indicate the sand deposits (sandbars and river delta). Brown line indicates wet-dry shoreline position. Red line marks a distance of $400 \mathrm{~m}$.

\section{Downdrift Beach Compartments - Rainbow Bay to Kirra}

Between 1930 and 1960, spits attached to Greenmount Hill were persistent features with a LSB usually extending from the headland to Kirra Beach. The spits were nourished by large $\left(\sim 500,000 \mathrm{~m}^{2}\right)$ offshore sand deposits building within Coolangatta Bay, as observed in 1961-1962. After the spit development, in few months (eg. 4 months - May to Sep.1961in Coolangatta Beach) the feature would weld to the upper beach and cause shoreline accretion, as it was observed in 1962 in Rainbow Bay and Coolangatta, and in 1963 in Kirra (Figure 3). This was the last naturally nourished bypassing observed prior to the training walls extension. 
The training walls obstruction to the sediment transport and the early 1970's storms led to long-term erosion of the downdrift beaches (Figure 3). In 1975, however, Coolangatta Beach shoreline started to accrete, as a consequence of Kirra groyne construction in 1972 and nourishments in 1974-75. In turn, Kirra Beach responded with maximum shoreline retreat, that persisted until early 2000's (Figure 3). Also in 1975, the first record of the LSB system that attaches to Point Danger and migrates towards Kirra was observed.

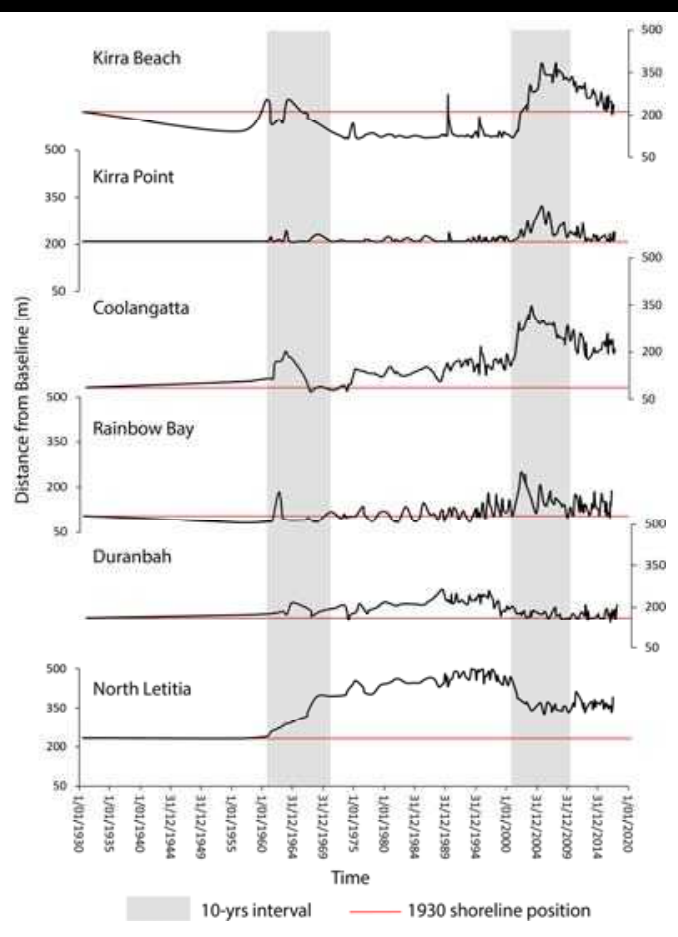

Figure 3. Shoreline changes from North Letitia to Kirra Beach during 90 years (1930-2017). Black line represents the average distance from baseline $(\mathrm{m})$ from each beach. Red line indicates the shoreline position in 1930. Grey shadow indicates a period of 10 years after training walls extension (1962-64) and artificial bypassing system (2001).

From 1996, the nourishments off Coolangatta Bay led to some shoreline accretion episodes. The sediment remained inside Coolangatta Bay for a while as offshore shoals, but the upper beach increase was not prolonged, particularly in Kirra Beach (Figure 3). This situation was reversed with the continuous sand input from the TSB. After a few months of TSB commencement, significant shoreline accretion occurred. In 2002-2003 major growth was observed in Rainbow Bay and Coolangatta upper beach (Figure 2 and 3), and by 2004-2006 in Kirra Beach. Strauss et al. (2009), analysing beach profiles from 1974 until 2006, also identified 2006 with having the maximum volume at Kirra Beach. This indicates that a sequential process of sand migration between the beach compartments from Rainbow Bay to Kirra takes $\sim 2-4$ years. From the early 1960's images, this process was observed to take around 2 years. This change in temporal scale of the process is assumed to be an outcome of the Kirra groyne obstruction.
During the early years of TSB, the upper beaches were frequently extending offshore of the tip of the headlands (Figure 2), supporting the formation of the "super (sand) banks" in 2002 and 2003, a prominent product of the artificial sand bypassing. After 2007-2008, some shoreline retreat was observed and the beach started to adjust into a new dynamic equilibrium. In summary, with a constant sediment supply, shoreline variability is observed to have a high-frequency in Rainbow Bay, most likely due to its alignment and position, as opposed to Coolangatta Beach that tends to retain sediment for a longer period, especially as an effect of Kirra groyne obstruction. Kirra Beach, on the other hand, is subject to sand bypassing from Coolangatta, which normally occurs through a longshore sandbar around the groyne.

In terms of sand bypassing in this region, the sandbar-spit bypassing observed frequently in the 1980-90's was reestablished after the adjustments of the TSB pumping rates (2007). Observing recent years (2015-2017), the process begins by infilling of Rainbow Bay upper beach, followed by a seaward migration of the LSB. Then, sand spits start to form downdrift of Greenmount Hill and Kirra groyne, first nourished by the LSB and after by sediment leaking around the headlands. As Rainbow Bay shoreline starts to retreat, the LSB migrates onshore, and therefore, the spit formations are pushed towards Coolangatta and Kirra upper beaches (Figure 2).

Acworth and Lawson (2011) proposed a seasonal fluctuation of Rainbow Bay shoreline that would interfere in the bypassing mechanism. The authors observed that the upper beach starts to infill from summer to autumn, which would push the LSB seaward. During winter, the spits are developed and by the end of this season, the onshore migration of the spits would be completed. From spring to summer, shorelines in Coolangatta Bay tend to retreat since the more NE wave conditions are not favourable to longshore sediment transport in the region. Additionally, the results from the morphological mapping suggest that the large offshore deposits in Coolangatta Bay, similar to those created during the nourishment campaigns, do not support LSB formation. Instead, the formation of the LSB requires sediment to migrate at a right angle around Point Danger-Snapper Rocks. Otherwise, the bypassing system will be compartmentalised between the three embayments by spits developing and, eventually, extending in a nearshore bar that leakes to the downdrift beach. After the estabilishment of the TSB system with a permanent outlet in Snapper Rocks, the development of this LSB has been continuous.

\section{DISCUSSION}

The Southern Gold Coast region illustrates the challenge of managing complex coastal areas with a diversity of constraints. The analysis showed that coastal interventions on the updrift have been the main drivers of the long-term trends for the study area. Tomlinson and Foster (1987) showed that the annual net northward longshore sediment transport that was able to bypass the Tweed River entrance was limited to 55\% during the first 20 years after the extension of the training walls. In this sense, the introduction of hard structures essencially creates a sediment budget issue that would be solved only with sediment availabity.

Hence, the natural recovery of the bypassing systems (river and headland) woud require the increasing of the longshore 
sediment transport rates, that is dependent on wave direction and energy (Vieira da Silva et al., 2016b). For instance, during the 1980 's, a re-establishement of the river delta and intermittent bypassing was noticed (Tomlinson and Foster 1987; Strauss et al., 2009). Indeed, in 1982-83 and 1986-87, large ebb delta shoals attached to a LSB along Letitia Spit were formed concurrent with some of the strongest El Niño events in the last century. Regionally, El Niño has been associated with shoreline progradation (Vos et al., 2019) - which was observed in those years - as it supports the SE wave climate and the northward longshore transport. A sequence of El Niño's is also reported in 1991 and 1994 while the progradation of Letitia Spit and the growth of the delta shoals were persistent. Apart from this condition, atypical high wave energy in 1988-1989 (Allen and Andrews, 1997) was able to migrate the LSB to the tip of the delta, making sediment available to bypass.

Nevertheless, this natural process is susceptible to climate changes as it depends on specific weather conditions to generate oblique and energetic waves that will reinforce the transport. Therefore, in a region where erosional trends create risks to coastal communities, relying on natural events to have sediment availabity may lead to coastal management issues. In this case, the introduction of an artificial sand bypassing system to mimic the natural sand transport would be the most viable solution.

In turn, the artificial bypassing will dominate the sediment transport and budget. With a jetty trapping efficiency of 70-80\% (Acworth and Lawson, 2011), sand availability to rebuild the delta was minimized and the natural sand bypassing of Point Danger became an even more sporadic event. Currently, it occurs mostly by the formation of a headland-attached LSB, in some cases related to erosion of Duranbah Beach. In the case of shutting down the artificial system, an erosional process would be triggered and would affect the downdrift beach compartments in sequence. The time to re-establish the dynamic equilibrium after the introduction of a permanent structure (training walls and artificial bypassing) varied between compartments. Overall, the adjustment period could be estimated as $\sim 5-15$ years for the upper beach and probably 20 years or more for the river delta. After this, trends are maintained if no further intervention or natural change occurs.

\section{CONCLUSION}

This study showed that a long-term and large image dataset is a powerful tool for morphodynamic analysis of individual compartments and regional interconnection. The 90-year analysis identified the consequences of coastal interventions on the sediment budget and equilibrium. The analysis also provided relevant conclusions for coastal management, by showing that interventions impact on the sediment balance between beach systems and the recovery time might vary around the decadalscale. This knowledge in combination with wave climate projections would support the coastal management of regions such as the Southern Gold Coast to reach a next level of engagement, such as recreational management of the sand transport by manipulating the LSB formation.

\section{ACKNOWLEDGMENTS}

This research was supported by the Griffith University through the Griffith University International Postgraduate
Research Scholarship (GUIPRS) and Griffith University Postgraduate Research Scholarship (GUPRS).

\section{LITERATURE CITED}

Allen, M. and Andrews, M.., 1997. Assessment of Directional Wave Climate Variability for a Sand Bypassing Project. In: Proceedings of the 13th Australasian Coastal and Ocean Engineering Conference and 6th Australasian Port and Harbour Conference; v.2.

Acworth, C. and Lawson, S., 2011. The tweed river entrance sand bypassing project ten years of managing operations in a highly variable coastal system. In: Proceedings of the 20th NSW Coastal Conference.

Araujo, R.S.; Silva, G.V.; Freitas, D.; Klein, A.H.F., 2009. Georreferenciamento de fotografias aéreas e análise da variação da linha de costa. In: J. Alcántara-Carrió, I.D. Correa, F. Ila, M. Alvarafo, A.H.F. Klein, J.A. Cabrera \& R. Sandoval (eds.), Métodos en Teledetección Aplicada a la Prevención de Riesgos Naturales en el Litoral, pp.123138, Cádiz, Espanha. ISBN: 978-84-96023-67-3.

Himmelstoss, E.A., 2009. DSAS 4.0 Installation Instructions and User Guide In: Thieler, E.R., Himmelstoss, E.A., Zichichi, J.L., and Ergul, Ayhan. 2009 Digital Shoreline Analysis System (DSAS) version 4.0 - An ArcGIS extension for calculating shoreline change.

Luijendijk, A., Hagenaars, G., Ranasinghe, R., Baart, F., Donchyts, G., and Aarninkhof, S., 2018. The State of the World's Beaches, Nature Scientific Reports, pp. 1-11.

Roelvink, J.A. and Murray, R.J., 1992. Gold Coast Queensland Australia: Southern Gold Coast littoral sand supply, Volume II, Delft Hydraulics Report H 85, October.

Strauss, D., Tomlinson, R. and Hunt, S., 2009. Profile Response and Dispersion of Beach Nourishment: Gold Coast, Australia. Journal of Coastal Research, SI 56 of the 10th International Coastal Symposium, Portugal.

Tomlinson, R.B. and Foster, D.N., 1987. Sand Bypassing at the Tweed River Entrance. In: Proceedings of the 8th Australasian Coastal and Ocean Engineering Conference, Launceston, I.E.Aust. Nat. Publ. No. 87/17, pp. 85-89.

Tomlinson, R.B., 1991. Processes of sediment transport and ebb tidal delta development at a jettied inlet. In: Proceedings of Conference on Quantitative Approaches to Coastal Sediment Processes, Washington-Seattle, pp.1404-1418.

Vieira da Silva, G., Muler, M., Prado, M.F.V., Short, A.D., Toldo Jr., E.E., Klein, A.H.F., 2016a. Shoreline changes analysis and insights into sediment transport path example of Santa Catarina Island North Shore, Brazil. Journal of Coastal Research, 32, 4, pp.863-874.

Vieira da Silva, G., Toldo Jr., E.E., Klein, A.H.F., Short, A.D., Woodroffe, C.D. 2016b. Headland sand bypassing quantification of net sediment transport in emabayed beaches, Santa Catarina Island North Shore. Marine Geology, 379, pp.13-27.

Vos K., Harley M.D., Splinter K.D., Turner I.L., 2019. Satellitederived shorelines along the east coast of Australia between 1987 and 2019. In: Proceedings of Australasian Coasts \& Ports 2019 Conference, Hobart, Australia. 